\title{
The application of multiloop diagnostics model to assess and improve the economic security of enterprises
}

\author{
Vladimir Pluzhnikov ${ }^{1, *}$, Sergei Kukharenko ${ }^{1}$, and Svetlana Shikina ${ }^{1}$ \\ ${ }^{1}$ Department of "Information technologies in economics", South Ural State University, 454080 Chelyabinsk, Russia
}

\begin{abstract}
The author's research is dedicated to the enhancement of the level of the enterprise economic safety. This task involves developing the concept of an integrated system for early prevention of dangers and threats of business activity, substantiation of procedures for regulating the activities of the enterprise in accordance with the changing external and internal factors. Multiloop diagnostics model is proposed to identify causal relations of management dysfunction. It allows you to receive an adequate assessment of the basic parameters of activity of the enterprise and accurately identify its status. Researching problems of economic safety of the enterprise such diagnostic methods as economic and logical analysis, statistical monitoring and strategic management were applied. There was made a conclusion that a qualitative assessment is a key tool of the level assessment of the enterprise economic safety, its control, and monitoring. It allows you to get reliable information about the real possibilities of the enterprise at different stages of development, to monitor and evaluate the level of economic security, find effective solutions to transition to a higher level of economic safety of the enterprise.
\end{abstract}

\section{Introduction}

An activity of any business entity in a market economy is characterized by a high level of uncertainty. It is connected to the presence of a large number of the environment external and internal factors, creating the security economic threats of the enterprise. The definition "economic security" is firmly included in the economic theory. The level of economic security and company's operating results are considered as interrelated characteristics of its successful functioning and sustainable development.

It is generally accepted the necessity to develop regulatory procedures and adaptation of the enterprise to changing external conditions with the aim to raise the level of economic security. It is necessary to develop a working system, which allows responding to various (internal and external) adverse changes (threats, dangers) of business development and their further neutralization.

This task is solved by using different tools. A number of authors consider that it's required to establish a system of threat diagnostics in the early stages of their manifestations [1, 2, 3]. However, it is a lack of theoretical research of applying this tool in order to enhance the economic security of the enterprise. In this paper methods of diagnosis are studied.

The goal of the research is to develop the concept of an integrated system for early prevention of internal and external dangers and threats to the business activities of the enterprise. The economic security concept of the enterprise based on the results of statistical monitoring allows selecting the functioning enterprise strategy based on the identification of the predicted state and receiving an adequate assessment of the parameters of its work.

\section{Factors of economic security}

Within the proposed concept, a set of threats impacting on economic security is considered as a system with a dynamic structure. It is necessary to know the structural elements and be able to predict the possible structural changes. In the functioning process of the enterprise, threat occurrence can lead to another threat, to enhancing their impact on the company's activity or to their neutralization.

The system of the enterprise economic security threats can be classified by various bases. The most significant threats to the system are the ones that give the possibility to minimize the riskiness of the activity, to bring in balance the enterprise internal potential to external conditions of the environment, as well as to ensure the process of its sustainable development in the long term period. Our vision for this issue agrees with the opinion of O.N. Gromova [4]. However, the list of dominant factors affecting the process of sustainable development should be supplemented. The proposed list of system factors is in table 1 .

Table 1. Factor system of the economic security category.

\begin{tabular}{|l|l|}
\hline \multicolumn{1}{|c|}{ Factor } & \multicolumn{1}{|c|}{ Content } \\
\hline Organizational & $\begin{array}{l}\text { Organizational structure of the enterprise, the } \\
\text { efficiency management system }\end{array}$ \\
\hline Financial & Regulating company financial issues, its paying \\
\hline
\end{tabular}

\footnotetext{
Corresponding author: pluzhnikovvg@susu.ru
} 


\begin{tabular}{|l|l|}
\hline & capacity and immune to bankruptcy \\
\hline $\begin{array}{l}\text { Technical } \\
\text { (technology) }\end{array}$ & $\begin{array}{l}\text { Creating and applying technology (competitive } \\
\text { ideas of scientific development) that enhance the } \\
\text { firm's competitiveness }\end{array}$ \\
\hline Information & $\begin{array}{l}\text { The level of information support of business, } \\
\text { information security, etc. }\end{array}$ \\
\hline Tax & $\begin{array}{l}\text { Regulating the optimality of tax burden and tax } \\
\text { administration }\end{array}$ \\
\hline Personnel & Recruitment and work with qualified personnel \\
\hline Legal & Legal maintenance of an organization activity \\
\hline $\begin{array}{l}\text { Spatial } \\
\text { geographical) }\end{array}$ & $\begin{array}{l}\text { The nature of the premises, the enterprise } \\
\text { territory, communications, the expandability }\end{array}$ \\
\hline $\begin{array}{l}\text { Socio- } \\
\text { environmental }\end{array}$ & A social security system degree of the personnel \\
\hline Innovative & $\begin{array}{l}\text { The level of an investment activity and the activity } \\
\text { on the financial market }\end{array}$ \\
\hline
\end{tabular}

This factor system takes into account the influence of the external internal environment at the level of the enterprise economic security. They form enterprise potential cooperating in the functioning process, both within the enterprise and in the external environment. The basis of this interaction is management processes that can cause certain threats and associated risks of the business operation.

\section{Diagnostics as type of the economic analysis}

There are two types of: with the regular management of the production process and with the implementation of enterprise development strategies (transition from its current state to the desired state). Accordingly, to run a company under these conditions you must know the source of the threat and the expected consequences. Control over processes can be provided by diagnostic tools, the set of which is shown in Figure 1.

In the economic literature, diagnostics is considered as a special type of economic analysis conducted referring to appearing financial problems of the company. A set of main definitions of the concept of diagnostics is given at table 2. As you can see the diagnostics are considered as a tool to get the reliable information about the real possibilities of an economic entity at any stage of its development. It serves to determine the reasons for changing the company state based on the conducted researches. Early threat diagnostics is a condition for ensuring the enterprise economic security.

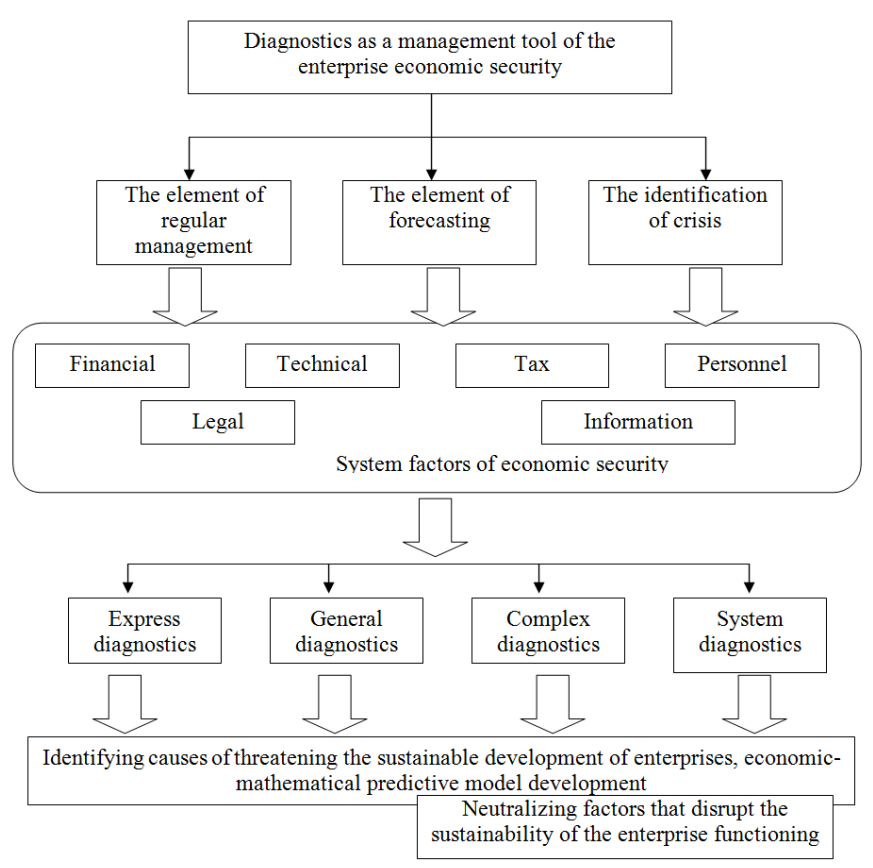

Fig. 1. Set of diagnostics tools.

Diagnostics of the enterprise economic security is a systematic and complex methodology of researching the features of business processes. The main task of diagnostics is to determine and evaluate signs of a multilateral process of deviation identification of parameters at the changes in external situations and internal operating conditions. Comparison of the received information with the normative values allows you to define a secure area of the enterprise $[5,6]$.

Table 2. The definition of the diagnostics.

\begin{tabular}{|l|l|}
\hline \multicolumn{1}{|c|}{ Author } & \multicolumn{2}{|c|}{ The content of definition "diagnostics" } \\
\hline $\begin{array}{l}\text { V.Kryzhanovskii, } \\
\text { V. Lapenkov, V. } \\
\text { Luter, [7] }\end{array}$ & $\begin{array}{l}\text { The estimation of parameters of the } \\
\text { organization state to determine the probability } \\
\text { of bankruptcy, the period and stage of the crisis }\end{array}$ \\
\hline J. Ohlson [8] & $\begin{array}{l}\text { Bankruptcy risk evaluation based on logistic } \\
\text { regression model of bankruptcy risk prediction }\end{array}$ \\
\hline V.V. Kovalev [9] & $\begin{array}{l}\text { A special kind of economic analysis for } \\
\text { prediction of possible bankruptcy }\end{array}$ \\
\hline $\begin{array}{l}\text { P.V. Gavrilov, } \\
\text { N.F. Shcherbakov } \\
\text { [10] }\end{array}$ & $\begin{array}{l}\text { The process of deviation identification in values } \\
\text { of economic activity of enterprises from mean } \\
\text { value }\end{array}$ \\
\hline $\begin{array}{l}\text { O.V. Efimova [11] } \\
\text { Evaluation category of the enterprise solvency } \\
\text { and liquidity to assess the enterprise bankruptcy } \\
\text { risk }\end{array}$ \\
\hline $\begin{array}{l}\text { V.Yu. Zhdanov [12] } \\
\text { Complex preventive tool for determining the } \\
\text { enterprise crisis processes }\end{array}$ \\
\hline $\begin{array}{l}\text { Yu.A. Loktionova } \\
\text { [13] }\end{array}$ & $\begin{array}{l}\text { A special process of abstract-logical operations, } \\
\text { inductive and deductive conclusion, which } \\
\text { begins with the developing a hypothesis }\end{array}$ \\
\hline $\begin{array}{l}\text { N. S. Maksakov[14] } \\
\text { The multilateral process of the assessment of } \\
\text { company activity, individual and specific } \\
\text { features }\end{array}$ \\
\hline $\begin{array}{l}\text { I.A. Koshkina, } \\
\text { E.R. Mubarashkina } \\
\text { [6] }\end{array}$ & $\begin{array}{l}\text { Analysis of parameters of external environment } \\
\text { and comparison of analytical results with } \\
\text { thresholds of indicators (danger zone) }\end{array}$ \\
\hline
\end{tabular}

It is important to emphasize that one of the diagnostics tasks is to determine the identities and leveling imbalances business processes development. Diagnostics enables you to identify a causal relationship of management dysfunction and then move to 
development a predictive and explanatory model of its development and functioning.

Establishment of an effective system of diagnostics of the enterprise economic security requires the following tasks:

- To overcome the information uncertainty of the threat assessment caused by a nonlinearity of the internal and external development of the environment.

- To choose methodological approaches those are most effective in predicting threats.

- To establish an effective diagnostic apparatus for the estimation of the transition state of the production system.

- To account the influence of development factors, the lifecycle of enterprise development, phase portrait of the external environment.

- To find a formalized model predicting system state, boundaries and the limits of structural and phase transitions.

The diagnostic is a process that is a set of logic operations, inductive and deductive conclusion. The diagnostics include a multilevel analysis, which is researching and exploratory and conducted on the basis of a systematic approach.

Applying the systematic approach in diagnostics is explained by the fact that the enterprise as an object cannot be isolated from the influence of the external environment. The enterprise should be considered both as a separate system (a subject, a set of subsystems, a business process) subject, a set of subsystems, business process), and as an element of a large social category (merger, holding, etc.), (fig. 2).

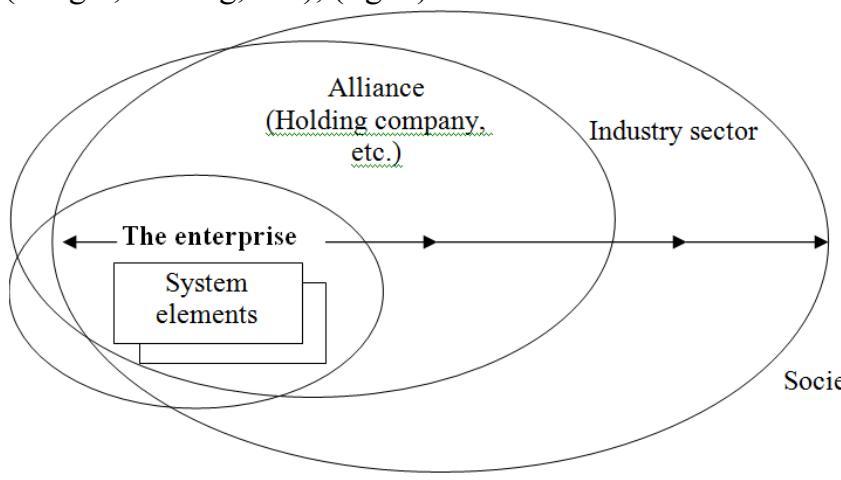

Fig. 2. System approach to the diagnostics.

The main direction of the diagnostic process is from analysis of complex indicators to the analysis of indicators of its constituent elements, from the analysis of the company results to the analysis of the factors of production and resources to forecasting future company activities.

The methodology of developing a system of diagnostics for ensuring the economic security of the enterprise is based on the following approaches: systemic, complex, quantitative, qualitative, behavioral, marketing, reproduction, normative, functional, substantive, operational, integrated, dynamic and situational $[15,16]$.

\section{Multiloop diagnostic model}

To solve problems related to the economic security of enterprises we propose to apply the multiloop diagnostic model, which is implemented on the principles presented in the table. 3 .

Table 3. The basic principles of diagnostics.

\begin{tabular}{|l|l|}
\hline \multicolumn{1}{|c|}{ Principle } & \multicolumn{1}{|c|}{ Description } \\
\hline Complexity & $\begin{array}{l}\text { Resource security (human, material, financial and } \\
\text { information) }\end{array}$ \\
\hline Timeliness & $\begin{array}{l}\text { Forecasting of threats, ranging from the initial } \\
\text { stage of the crisis }\end{array}$ \\
\hline Continuity & $\begin{array}{l}\text { Constant monitoring and continuous improvement } \\
\text { of the system }\end{array}$ \\
\hline Activity & $\begin{array}{l}\text { Active monitoring of competitors to perform an } \\
\text { effective protection }\end{array}$ \\
\hline Legality & $\begin{array}{l}\text { Economic security system corresponds to the laws } \\
\text { of the Russian Federation }\end{array}$ \\
\hline $\begin{array}{l}\text { Economic } \\
\text { efficiency }\end{array}$ & $\begin{array}{l}\text { Comparing potential damage and the cost of the } \\
\text { diagnostics }\end{array}$ \\
\hline Differentiation & $\begin{array}{l}\text { Security system should be most suitable for the } \\
\text { organization }\end{array}$ \\
\hline $\begin{array}{l}\text { Cooperation and } \\
\text { coordination }\end{array}$ & $\begin{array}{l}\text { An interaction of services to ensure optimal } \\
\text { functioning of the whole organization }\end{array}$ \\
\hline Perfectibility & $\begin{array}{l}\text { Optimization of the activity of enterprise services } \\
\text { on the basis of the appearance of new mechanisms }\end{array}$ \\
\hline $\begin{array}{l}\text { Centralization of } \\
\text { management }\end{array}$ & $\begin{array}{l}\text { Diagnostics system should operate as an } \\
\text { independent control function }\end{array}$ \\
\hline
\end{tabular}

Presented principles cover the enterprise completely from all sides (outside and inside), Figure 2. The conceptual basis of the researches of the enterprise is the multiloop diagnostic model, Figure 3.

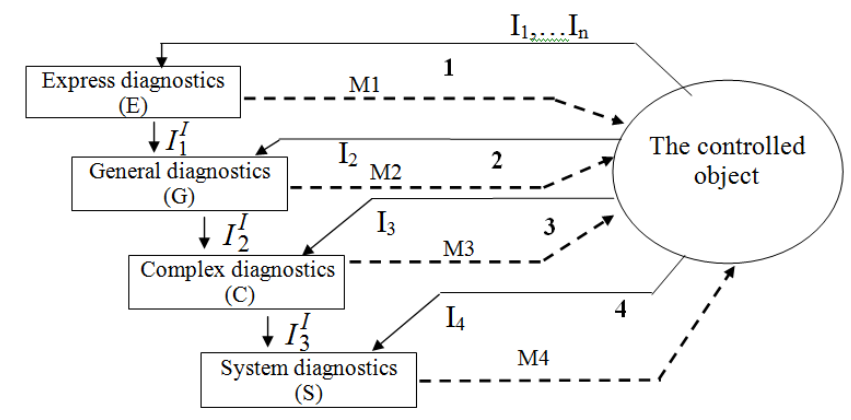

1,2,3,4 - stages of diagnostics; $I_{1,2} \ldots I_{n}$-information(the parameter type of the state) of automation control object; M1, M2, M3, M4 - management actions by the results of the particular diagnostics stage

Fig. 3. Multiloop diagnostics model in the anti-crisis management.

Multiloop diagnostic model is an implementation of a systematic approach when analyzing the enterprise state and allows you to optimize the resource usage through the multi-step analytical procedures with making the partial decisions. A systematic approach is through consistent, multistage approach to identify the causes of those or other crisis processes and their specifications. The content of the diagnostics stages is presented in table 4.

Table 4. The content of the diagnostics stages.

\begin{tabular}{|l|l|}
\hline $\begin{array}{c}\text { Name of a } \\
\text { stage }\end{array}$ & \multicolumn{1}{c|}{ Contents } \\
\hline $\begin{array}{l}\text { Express } \\
\text { diagnostics }\end{array}$ & $\begin{array}{l}\text { Dynamic analysis of financial indicators, identification } \\
\text { of factors causing the dynamics of financial indicators }\end{array}$ \\
\hline
\end{tabular}




\begin{tabular}{|l|l|}
\hline $\begin{array}{l}\text { General } \\
\text { diagnostics }\end{array}$ & $\begin{array}{l}\text { Identifying the cause factors of production dynamics, } \\
\text { assessment of resource effectiveness, identifying the } \\
\text { causes of the crisis (the type of crisis situation and } \\
\text { factors) }\end{array}$ \\
\hline $\begin{array}{l}\text { Complex } \\
\text { diagnostics }\end{array}$ & $\begin{array}{l}\text { Analysis of the enterprise management system, the } \\
\text { parameters of the interrelation and interdependence of } \\
\text { production factors }\end{array}$ \\
\hline $\begin{array}{l}\text { System } \\
\text { diagnostics }\end{array}$ & $\begin{array}{l}\text { Developing the economic-mathematical models of } \\
\text { business processes, analysis of resource potential, } \\
\text { forming set of criteria (institutional rules, corporate } \\
\text { standards) adequately reflecting the specifics of the } \\
\text { enterprise activity }\end{array}$ \\
\hline
\end{tabular}

Multiloop diagnostics model is a reflexive technology of management decisions support at all threats development stages even when the threat causes detection is difficult or impossible.

The diagnostics objectives and content of the analytical procedures are determined by the enterprise specificity [14] and features of the selected analysis type (problem-oriented, forward-looking, operational, etc.).

In the multiloop model of diagnostics, studies begin with the stage of express diagnostics (E) of the enterprise (controlled object) that includes information flow about parameters of the controlled object of (I1), and management action (M1) (fig. 3).

At the first stage of the express diagnostics, the following analysis is conducted: financial performance of enterprises, the structure of assets and sources of their formation, financial performance, a comparison of planned and actual indicators and their dynamics.

At this stage, there are periods that characterized by different behaviors (dynamics) of the initial data, the analysis of initial; data includes:

- periodization (identification of process chronology) and identification of turning points (borders of periods based on dynamic analysis of financial indicators);

- identification of factors causing the dynamics of financial indicators.

At this stage, decisions are made (M1 at Fig. 3) about the rules for the formation of an information database, compares planned (corporate standards or reference) and actual parameters of the enterprise, the specific techniques and research frames for the general diagnostics are identifying. According to the analysis results, there is an evaluation of improvement or deterioration of the enterprise state.

At the second stage there is the general diagnostics (G) of the controlled object that consists of information flow I2 and management action M2 at Figure 3).

At this stage, we identify what group or set the researched object belongs to. Then we evaluate the degree of importance of each group of indicators that is corrected according to the evaluation results of lifecycle stage of the enterprise development [17], the economic sustainability, $[18,19,20]$, the identification of business processes [21]. Then factor parameters are identified: technical, production, efficiency and resources usage, etc. $[22,23]$. The quantitative assessment of parameters dynamic is conducted is conducted and dynamic characteristics are defined.

Assumptions about the applicability of specific factors based on the assumptions about the properties of identifiable models (like its linear homogeneity). The methods of market analysis, the lifecycle analysis, the investment activity analysis, efficiency analysis are chosen. At this stage, decisions about the choice of factor model are made (ROI, EVA ROA, etc.) for factor analysis of the enterprise.

The third stage includes a complex diagnostics (C) of the controlled object management (information flow I3 and management action M3, Figure 3).

At this stage the following analysis are held: the properties of the production factors (the study of organizational-technical level of enterprises, logistics, resource efficiency, etc.) and the parameters of their interaction; analysis of potential development organization $[24,25,26]$; indicators of statics and dynamics parameters of external and internal environment; efficiency control system (reflexive properties, mechanism of control, elements of corporate culture, the level of institutionalization process of managerial decision-making, etc.); the level of economic security of the enterprise management system.

Based on the results of the analysis of the properties of the enterprise management system, the set of evaluation criteria of what particular class the researched object belongs is corrected.

The fourth stage contains system diagnostics (S) of the controlled object (information flow I4, management action M4, fig. 3).

At this stage there are:

- analysis of the potential of the enterprise development (the potential of labor resources, intangible assets as the competitive advantages of the enterprise are determined by their potential);

- analysis of the quality of corporate standards ( institutional rules of the enterprise), the institute of education (development) including subject management system;

- development of economic-mathematical models of business processes, and the sustainability of the development.

The basic economic institutions are actualized in institutional norms, values, philosophy and mission of the enterprise. The diagnostics at this stage involves the identification and classification of new factors that cause the dynamics of the parameters of the controlled object (business processes). The parameters of new factors are included in the monitoring system of the enterprise.

The scheme (fig. 3) is elaborated on the principle "from the general to the special". It displays the combination of diagnostics methods and the enterprise management processes as a management tool for the economic security. Economic security management involves the consistent standard application which may be corrected depending on the conditions of the enterprise strategy.

\section{Conclusion}

Thus, applying the multiloop diagnostics model helps to improve the economic security of the enterprise due to prompt response to the external and internal threats; to find the effective decisions of the problem switching to the next level of economic security with different 
combinations of resources; to elaborate monitoring system of the enterprise efficiency based on differentiated tools and the implementation measures for the enterprise sustainable development.

It helps to improve a resource effectiveness of the enterprise, a reliability, and accuracy of business process identification within the development strategy of the enterprise and to predict the desired state of the economic security of business operations.

The work was supported by Act 211 Government of the Russian Federation, contract № 02.A03.21.0011

\section{References}

1. M. Bendikov, Management in Russia and abroad, 2, 7 (2000)

2. V. Mamontov, O. Stepicheva, Bulletin of the University of Tambov series: the humanities, 12(104) (2011)

3. V. Tambovcev, Bulletin of MSU, Series 6, Economics, 3 (1999)

4. O. Gromova, The world of science, culture and education, 3(52), 34 (2015)

5. I. Gusev, The economic security of businesses (EDP sciences, Moscow, 2006)

6. I. Koshkina, E. Mubarakshina, Contemporary studies of social problems (electronic journal), 8(16) (2012)

7. V. Kryzhanovskii, V. Lapenkov, V. Luter, Anti-crisis management: A training manual for technical colleges (Publishing House "PRIOR", Moscow, 1998)

8. J. Ohlson, J. of Accounting Research, 19 (1980)

9. V. Kovalev, O. Volkova, Activity analysis (Prospect, Moscow, 2004)

10. P. Gavrilov, N. Shcherbakova, The economic analysis: theory and practice, 13(412), (2015)

11. O.V. Efimova, How to analyze the financial situation of an enterprise (Business-shk. INTEL-SINTEZ, Moscow, 1994)
12. V.Yu. Zhdanov, Management of economic systems, 32 (2011)

13. Yu. Loktionova, Social and phenomena and processes, 4(050), 88 (2013)

14. N. Maksakov, Social and phenomena and processes, 12(46), 202 (2012)

15. G. Kleiner, “A business strategy,” Analytical Handbook (KONSJeKO, Moscow, 1998)

16. O. Molchanova, T. Aliev, Bulletin of ASTU, 4(45), 43 (2008)

17. V. Pluzhnikov, S. Shikina, Finance and credit: economic analysis, 44(443), 53 (2015)

18. V. Mokeev, M. Nelyubina, Bulletin of the South Ural State University. Series: Computational mathematics and informatics, 5(1), 69 (2016)

19. V. Mokeev, O. Buslaeva, S. Voronina, V. Pluzhnikov, S. Shikina, Applying the eigenstates for the analysis and forecasting of socio-economic systems (SUSU, Chelyabinsk, 2015).

20. E. Salimonenko, A. Karpushkina, O. Volozhanina Bulletin of the South Ural State University. Series: Economic and management, 44(303), 80 (2012)

21. S. Kukharenko, V. Pluzhnikov, S. Shikina, Bulletin of the South Ural State University. Series: Economics and management, 9(4), 57 (2015)

22. V. Pluzhnikov, S. Shikina, Management of economic systems (electronic journal), 10, (2014).

23. D.Suleymanova, S. Rabadanova, Economics and entrepreneurship, 11(52-2), 388 (2014)

24. E. Vyborova, E. Salyahova, The economic analysis: theory and practice, 12(315), 23 (2013)

25. L. Kiyashchenko, Yu. Kolesnikova, Problems of socio-economic development of the regions $A$ collection of articles of the international scientifically-practical (2015)

26. L. Mikhalina, E. Golovanov, Bulletin of the South Ural State University. Series: Economics and management, 8(3), 41 (2014) 